\title{
Gravimetric Determination of Soil Organic Matter
}

\author{
M. Miyazawa ${ }^{1 *}$, M.A. Pavan ${ }^{1}$, E.L. de Oliveira ${ }^{1}$, M. Ionashiro ${ }^{2}$ and A.K. Silva ${ }^{3}$ \\ ${ }^{1}$ IAPAR, C. Postal 481, CEP 86001-970, Londrina - PR, Brazil;. ${ }^{2}$ UNESP, Inst. Química, C. Postal 355, CEP \\ 14800-900, Araraquara-SP, Brasil;. ${ }^{3}$ UEL, C. Postal 6001, CEP 86051-970, Londrina - PR, Brazil
}

\begin{abstract}
Studies were carried out to evaluate a gravimetric method for the determination of soil organic matter by the mass loss at $300^{\circ} \mathrm{C}$. The gravimetric method was compared with Walkley-Black, using several brazilian soils with variable chemical and physical properties. Gravimetric method was positively correlated with Walkley-Black method with the following linear regression equation: $y=3.72 x+0.29, r=0.94$. The angular coefficient 3.72 for tropical soils was greater than those reported in the literature for temperate soils (from 1.68 to 2.13). The difference was due to greater oxidation degree of the organic matter. When compared with Walkley-Black method, gravimetric technique showed certain distinct advantages such as no environmental contamination with $\mathrm{Cr}^{6+}$ and improved laboratory safety eliminating the use of concentrated sulfuric acid.
\end{abstract}

Key words: organic carbon, thermogravimetry, soil analysis.

\section{INTRODUCTION}

The importance of soil organic matter on physical, chemical, and biological properties of soil with implications on erodibility, nutrient cycling, water storage and resultant soil productivity is well established. These efficiencies affect both crop production and natural resources sustainability, and they are mutually reinforcing.

Soil organic matter is usually evaluated through determination of organic carbon. Several techniques have been developed for measuring soil organic carbon, such as Walkley-Black(WB) (Jackson, 1982), gravimetry (Ball, 1964; Ben-Dor \& Banin, 1989), thermogravimetry (Wendlandt, 1986; Beltran et al., 1988), and chromatography (Dean, 1974). The Walkley-Black method is based on organic carbon oxidation by $\mathrm{Cr}^{6+}$ in the presence of concentrated $\mathrm{H}_{2} \mathrm{SO}_{4}$. The excess of $\mathrm{Cr}^{6+}$ is titrated with $\mathrm{Fe}^{2+}$ or determined by spectrophotometry with $\mathrm{Cr}^{3+}$ formation. Gravimetric and thermogravimetric methods are based on mass loss, respectively, by incineration and heating.

The majority of brazilian soil laboratories uses the WB method due to its higher speed and simple instrumentation. However, the disadvantages of the WB method are the use of concentrated $\mathrm{H}_{2} \mathrm{SO}_{4}$ and the presence of $\mathrm{Cr}^{6+}$. Gravimetric determination of soil organic matter was used before WB method. However, it was abandoned due to low analytical velocity and difficulty for automation in the laboratory. The objectives of the present study were to re-evaluate the gravimetric method for routine determination of soil organic carbon and to determine the organic carbon/organic matter (OC/OM) ratio of the tropical soils.

\section{MATERIALS AND METHODS}

Thermogravimetric method (TGA) - ten milligrams of soil sample $(<200 \mu \mathrm{m})$ were used for analysis in a TGA Dupont instrumentation, model 5000. Heating increment was $15^{\circ} \mathrm{C} \mathrm{min}{ }^{-1}$ in the interval from 25 to $600^{\circ} \mathrm{C}$ with atmosphere air. Brazilian soil samples were selected containing organic matter varying from 10 to $100 \mathrm{~g} \mathrm{~kg}^{-1}$. The organic matter was determined by the mass loss in the interval from 110 to $420^{\circ} \mathrm{C}$ in the thermogravimetric curve.

Differential scanning calorimetry method (DSC) one hundred milligrams of soil samples

\footnotetext{
* Author for correspondence
} 
$(<200 \mu \mathrm{m})$ were used for analysis in a DSC DuPont instrumentation model 2000. Heating increment was $15^{\circ} \mathrm{C} \mathrm{min}{ }^{-1}$ in the interval from 25 to $600^{\circ} \mathrm{C}$ in atmosphere air and $\mathrm{N}_{2}$.

Walkley-Black method (WB) - one gram of soil sample was transferred to $250 \mathrm{ml}$ Erlenmeyer and added $10 \mathrm{ml}$ of $1 \mathrm{~N} \quad \mathrm{~K}_{2} \mathrm{Cr}_{2} \mathrm{O}_{7}$ and $10 \mathrm{ml}$ of concentrated $\mathrm{H}_{2} \mathrm{SO}_{4}$. After 30 minutes, $50 \mathrm{ml}$ of deionized water, $3 \mathrm{ml}$ of concentrated $\mathrm{H}_{3} \mathrm{PO}_{4}$ and $0,5 \mathrm{ml}$ of $1 \%$ defenilamina indicator were added. Then, titrated slowly with $1 \mathrm{~N} \mathrm{FeSO}_{4}$ solution up to a green color end point.

Gravimetric method (GM) - one gram of soil sample was transferred to $10 \mathrm{ml}$ becker and incinerated in an electric muffle for 1 hour at 250, 300,350 , and $400{ }^{\circ} \mathrm{C}$. Incineration time of $0.5,1.0$, 2.0 , and 4.0 hours at $300^{\circ} \mathrm{C}$ was also evaluated.

Total organic carbon (TOC) - Total soil carbon was oxidized to $\mathrm{CO}_{2}$ at $800^{\circ} \mathrm{C}$ in atmosphere air, and determined by thermic conductivimetry.

\section{RESULTS AND DISCUSSION}

Thermogravimetric diagram for a red latossol with $19.8 \mathrm{~g} \mathrm{~kg}^{-1}$ of carbon is shown in Figure 1.

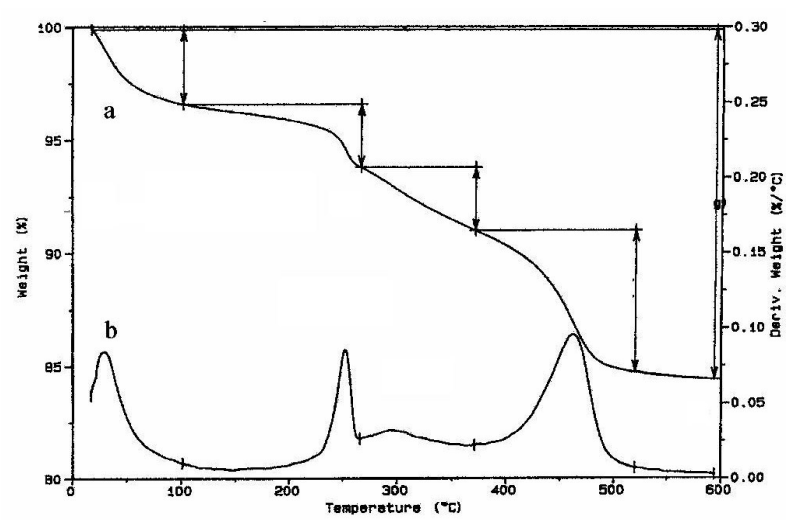

Figura 1 - Thermogravimetric diagram for red latossol with $19.8 \mathrm{~g} \mathrm{~kg}^{-1}$ of carbon in atmosphere - air $100 \mathrm{~mL}$ $\min ^{-1}$. (a) relative mass loss, (b) differential mass loss.

The diagram showed four characteristic regions in the interval from 25 to $600{ }^{\circ} \mathrm{C}$. The first region $(<$ $\left.100^{\circ} \mathrm{C}\right)$ showed that mass loss $\quad(0.383 \mathrm{mg})$ was mainly due to water volatilization; in second region $\left(200-280^{\circ} \mathrm{C}\right)$, the mass loss $(0.323 \mathrm{mg})$ was mainly due to decomposition of organic matter, mainly carboxylic and phenolic functional groups of the humic and fulvic acids and hydrocarbon compounds. In the second region the mass loss could also be due to release of low molecular weight organic compounds (Wendlandt, 1986; Beltran et al., 1988). The third region (270$\left.370^{\circ} \mathrm{C}\right)$ had the mass loss $(0.324 \mathrm{mg})$ mainly due to carbon oxidation of the organic matter (R$\mathrm{CH}+\mathrm{O}_{2} \rightarrow \mathrm{CO}_{2}+\mathrm{H}_{2} \mathrm{O}$ ). In fourth region (380 $\left.530^{\circ} \mathrm{C}\right)$, the mass loss $(0.726 \mathrm{mg})$ was mainly due to dehydroxilation of metallic hydroxides $(\mathrm{M}-\mathrm{OH}$ $\rightarrow \mathrm{MO}+\mathrm{H}_{2} \mathrm{O}$, were $\mathrm{M}=\mathrm{Al}, \mathrm{Fe}, \mathrm{Mn}$ and other metals).

Calorimetric diagrams in atmosphere air and in $\mathrm{N}_{2}$ for the interval between 25 to $600^{\circ} \mathrm{C}$ are shown in figures 2 and 3, respectively.

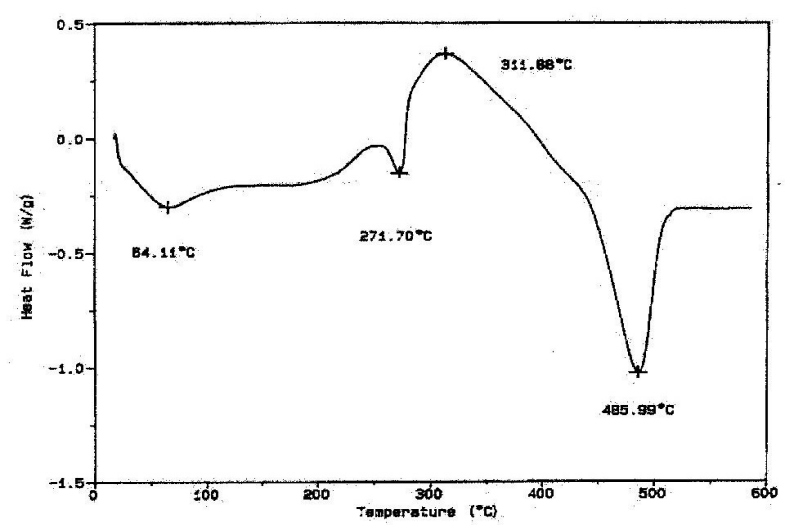

Figura 2 - Calorimetric diagram in atmosphere air 100

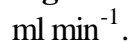

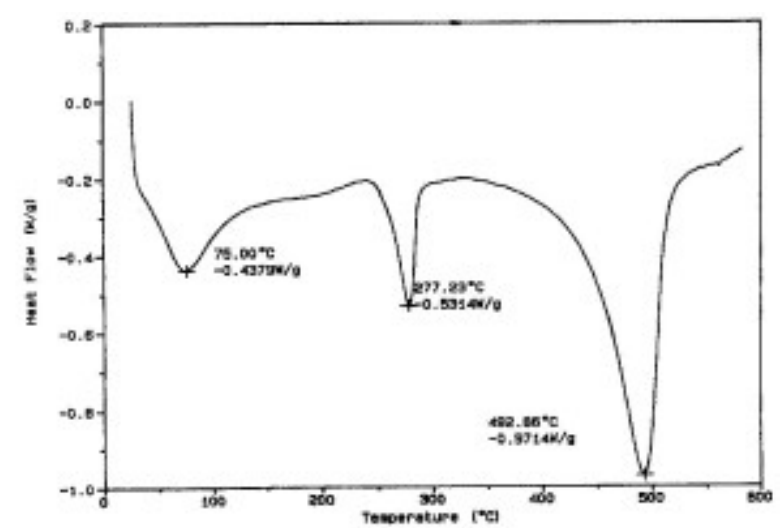

Figura 3 - Calorimetric diagram in atmosphere $\mathrm{N}_{2}$ $100 \mathrm{~mL} \mathrm{~min}^{-1}$

The first endothermic peak appeared at 60 and $75^{\circ} \mathrm{C}$ in air atmosphere and $\mathrm{N}_{2}$, respectively, corresponding to the loss of water molecules observed in the thermogravimetric curve (Figure 1). The second endothermic peak was observed at 271.7 and $277.23{ }^{\circ} \mathrm{C}$ in air atmosphere and $\mathrm{N}$, respectively corresponding to dehydroxilation and 
decarboxilation of organic compounds. The greater peak for the $\mathrm{N}_{2}$ in relation to air, suggested a partial oxidation of organic matter. The decomposition of organic matter caused a peak at $475{ }^{\circ} \mathrm{C}$ in $\mathrm{N}_{2}$ only. The exothermic peak between 275 and $470^{\circ} \mathrm{C}$ in air atmosphere only corresponded with the mass loss observed in the thermogravimetric diagram $>270^{\circ} \mathrm{C}$ (Figure 1). Both thermogravimetric and calorimetric diagrams suggested that thermic decomposition of organic matter in soil occured between 200 and $280^{\circ} \mathrm{C}$ and the oxidation of carbon between 270 and $420^{\circ} \mathrm{C}$.

The WB method was highly correlated with mass loss by incineration at $250,300,350$, and $400^{\circ} \mathrm{C}$, presenting the following linear regression equations, respectively: $\mathrm{y}=3.369 \mathrm{x}+0.2716, \mathrm{r}=$ $0.923 ; \mathrm{y}=3.720 \mathrm{x}+0.2914, \mathrm{r}=0.937 ; \mathrm{y}=4.054 \mathrm{x}$ $+0.5046, \mathrm{y}=0.934$ and $\mathrm{y}=4.298 \mathrm{x}+0.5357, \mathrm{r}=$ 0.933 .

Figure 4 presents the relationship between WB and incineration at $300^{\circ} \mathrm{C}$ methods. The mass loss by thermogravimetry $\left(110\right.$ and $\left.420^{\circ} \mathrm{C}\right)$ and by incineration at $300^{\circ} \mathrm{C}$ was also highly correlated $(\mathrm{y}=1.0556 \mathrm{x}+0.1632, \mathrm{r}=0.986)$. The mass loss by incineration $\left(300^{\circ} \mathrm{C}\right)$ for $0.5,1.0,2.0,4.0$, and $18.0 \mathrm{~h}$ was exactly the same for all times. These results showed that the soil organic matter was completely decomposed at $300^{\circ} \mathrm{C}$ for 30 minutes of incineration.

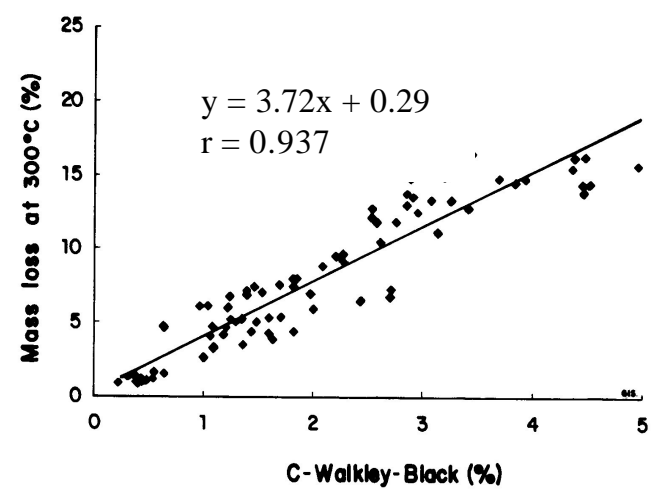

Figure 4 - Correlation between WB and incineration at $300^{0} \mathrm{C}$.

The WB and incineration at $300^{\circ} \mathrm{C}$ methods were compared with soil organic carbon oxidized by $30 \% \mathrm{H}_{2} \mathrm{O}_{2}$ (Table 1). The $\mathrm{H}_{2} \mathrm{O}_{2}$ oxidized more than $80 \%$ of the total organic carbon. The relationships between WB and incineration methods before and after $\mathrm{H}_{2} \mathrm{O}_{2}$ oxidations was, respectively: $\mathrm{y}=$
$3.620 \mathrm{x}+4.562, \mathrm{r}=0.861$ and $\mathrm{y}=18.04 \mathrm{x}+14.42$, $\mathrm{r}=0.760$. The increase in the angular coefficient from 3.62 to 18.04 suggested an increase in the oxidation of residual soil organic carbon. The WB method was also highly correlated with total organic carbon $(\mathrm{y}=0.918 \mathrm{x}+0.368, \mathrm{r}=0.992)$. These results showed high precision of the WB method, and the possible interferences by $\mathrm{Cl}^{-}$and $\mathrm{Fe}^{2+}$ ions are negligible.

Table 1 - Organic matter determination by incineration at $300^{\circ} \mathrm{C}$ and carbon by WB in soils before and after oxidation by $30 \% \mathrm{H}_{2} \mathrm{O}_{2}$.

\begin{tabular}{ccccc}
\hline \multirow{2}{*}{ Soil } & \multicolumn{2}{c}{ Before oxidation } & \multicolumn{2}{c}{ After oxidation } \\
\cline { 2 - 5 } No & WB & Incineration & WB & Incineration \\
\hline & & & & \\
& & & & \\
1 & 44.6 & 138.4 & 5.5 & 98.2 \\
2 & 43.6 & 154.4 & 7.2 & 106.8 \\
3 & 10.5 & 60.1 & 5.0 & 49.2 \\
4 & 13.7 & 34.3 & 4.6 & 25.4 \\
5 & 33.5 & 147.3 & 8.1 & 124.5 \\
6 & 14.0 & 0.5 & 2.7 & 47.9 \\
7 & 18.3 & 43.2 & 2.2 & 8.3 \\
8 & 38.4 & 145.2 & 6.1 & 108.3 \\
9 & 27.2 & 72.2 & 3.0 & 20.2 \\
10 & 21.1 & 58.6 & 2.3 & 14.8 \\
11 & 28.6 & 137.2 & 4.4 & 98.4 \\
12 & 22.1 & 94.7 & 2.9 & 67.7 \\
13 & 25.4 & 127.0 & 4.0 & 95.8 \\
14 & 32.0 & 148.6 & 5.0 & 109.1 \\
15 & 16.1 & 41.6 & 4.1 & 19.7 \\
\hline
\end{tabular}

Determinations of organic matter in several brazilian agriculture soils by WB and mass loss at $300^{\circ} \mathrm{C}$ methods showed high correlation (Figure 4). The angular coefficient of 3.72 was much higher than those reported in the literature. Studies with different soils where WB method was compared with thermogravimetric method showed angular coefficient of 2.13 (Dean, 1974), 1.68 (Giovannini et al., 1985), 2.05 (Ben-Dor \& Banin, 1989) and 1.724 (Jackson, 1982). The greater angular coefficient of the brazilian soils (3.72) was probably due to higher oxidation degree of the organic matter. In other words, the organic molecules of the tropical soils presented a greater number of functional groups with oxygen atoms. such as $\mathrm{R}-\mathrm{COOH}, \mathrm{R}-\mathrm{C}=\mathrm{O}$, R-COH, and others. Therefore, for the brazilian soils the estimation of 
soil organic matter could be obtained by determining the mass loss at $300^{\circ} \mathrm{C}$ and solving the linear regression $[\mathrm{x}=(\mathrm{y}-0.29) / 3.72)]$. Where $\mathrm{x}=$ organic carbon and $\mathrm{y}=$ mass loss at $300^{\circ} \mathrm{C}$. This factor was higher than that used in the majority of brazilian soil laboratories (Raij \& Quaggio, 1983). It was important to note that the factor used in the brazilian soil laboratories is the same suggested by Jackson (1982) for north american soils.

Determinations of organic carbon by WB and thermogravimetric methods in soil samples used in the international soil analysis program coordinated by the Wageningen University showed the following linear regression $\quad \mathrm{y}=1.55 \mathrm{x}+$ $6.66 r=0.94$. Soil samples coefficient was 1.55 which was closer to those reported in the literature (Ball, 1964; Jackson, 1982; Ben-Dor \& Banin, 1989). These results suggested that the higher organic matter/organic carbon (OM/OC) ratio of the brazilian soils was due to higher oxidation degree of the organic matter. Determinations of organic carbon from organic residues by WB and incineration at $300^{\circ} \mathrm{C}$ methods were also highly correlated $(\mathrm{y}=1.606 \mathrm{x}-0.1704, \mathrm{r}=0.995)$. The regression coefficient of 1.606 was closer to 1.680 found for sewage sludges (Giovannini et al., 1985).

\section{CONCLUSIONS}

Gravimetric method could be used for determination of organic matter in routine soil analysis with advantages of eliminating $\mathrm{Cr}$ and concentrated $\mathrm{H}_{2} \mathrm{SO}_{4}$. Tropical brazilian soils presented higher $\mathrm{OM} / \mathrm{OC}$ relationship.

\section{AKNOWLEDGEMENT}

We thank Profs. Dr. Ana M. G. Plepis and Dr. Salvador Claro Neto Instituto de Química - USP. São Carlos - SP. for their help in determining DSC and TGA curves of the soils.

\section{RESUMO}

Avaliou-se o método de determinação gravimétrica da matéria orgânica do solo pela perda de massa por incineração a $300^{\circ} \mathrm{C}$ e comparou-se com o carbono determinado pelo método Walkley-Black. Os dois métodos foram correlacionados positivamente com a seguinte equação de regressão linear: $y=3,720 x+0,2914$. $\mathrm{r}=0,937$. O coeficiente. 3,720 foi maior do que os encontrados na literatura. que variaram de 1,68 a 2,13. Esta diferença foi atribuída ao maior grau de oxidação da matéria orgânica dos solos das regiões tropicais. O método de incineração é aplicável para determinação do $\mathrm{C}$ do solo em rotina. $\mathrm{O}$ método não contamina o meio ambiente com metal tóxico $\left(\mathrm{Cr}^{6+}\right)$ e não oferece riscos aos analistas com o uso de ácido sulfúrico concentrado.

\section{REFERENCES}

Ball, D. F. (1964). Loss-on-ignition as an estimate of organic matter and organic carbon in non calcareous soils. Journal of Soil Science, London, v.15, p.84-92

Beltrán, V.; Blasco, A.; Escardino, A. \& Negre, F. (1988). Formation of black core during the fring of floor and wall tiles. Interceram, Freiburg, v.37, p.1521

Ben-Dor, E. \& Banin, A. (1989). Determination of organic matter content in arid zone soils using a simple "Loss - on - ignition" method. Commun. Soil Sci. and Plant Anal., New York, v.20, p.16751695.

Dean, J. W.E. (1974). Determination of carbonate and organic matter in calcareous sediments and sedimentary rocks by loss on ignition: comparison with other methods. Journal of Sedimentary Petrology, New York, v.44, p.242-248.

Giovannini, G.; Riffaldi, R. \& Levi-Minzi, R. (1985). Determination of organic matter in sewage sludges. Commun. Soil Sci. Plant Anal., New York, v.16. p.775-785.

Jackson, M.L. (1982). Análisis químico de suelos. Barcelona: Ediciones Omega, p.282-309.

Raij, B. Van; Quaggio, J.A. (1983). Método de análise de solo para fins de fertilidade. Campinas: IAC, p.31 (Boletim Técnico. 81)

Wendlandt, W.W. M. (1986). Thermal analysis. New York: J. WILEY \& SONS, p.137-460. 